\title{
Mapping of buried tunnel valleys in Denmark: new perspectives for the interpretation of the Quaternary succession
}

\author{
Flemming Jørgensen and Peter B.E. Sandersen
}

Tunnel valleys eroded by subglacial meltwater underneath the Late Weichselian ice sheet are a common feature in the Danish landscape (Ussing 1907; Smed 1998). They occur as undulating elongate depressions with hollows and thresholds and without continuously descending floors. The valleys rise tens of metres before terminating in large outwash fans, primarily along the Main Stationary Line in Jylland, but also along younger ice-margin lines formed shortly after the Last Glacial Maximum. The meltwater was driven by hydrostatic pressure gradients below the glacier towards its margin leading to subglacial erosional features, partly in the form of valleys. The term 'tunnel valley' was first used by Madsen (1921), who referred to tunnel-like structures below glaciers that were expected to have carried the meltwater. Worldwide, this term is used for subglacially eroded valleys; however, other terms such as 'tunnel channel' and 'incision' are also widely used for such valleys.

There is general consensus that subglacial meltwater is the primary causative agent that has eroded the tunnel valleys (O’Cofaigh 1996; Huuse \& Lykke-Andersen 2000; Jørgensen \& Sandersen 2006). The subglacial origin is indicated by: (1) abrupt terminations at former ice margins and the association with the large outwash plains, (2) irregular longitudinal profiles, (3) the occurrence of small channels and eskers in the valleys, and (4) the non-meandering and non-dendritic appearance of the relatively straight-segmented valleys. The exact mode of meltwater erosion remains, however, poorly understood. Valleys are present not only in the landscape; they are also found buried in the subsurface. In Denmark, buried valleys have occasionally been described on the basis of borehole data and early geoelectrical methods (e.g. Sorgenfrei \& Berthelsen 1954; Lykke-Andersen 1973; Binzer \& Stockmarr 1994). Based on the large amount of newly collected hydrogeophysical data in Denmark, it has recently become possible to define such valleys as tunnel valleys

Fig. 1. Two selected areas with high densities of mapped buried valleys. A: North-western part of Jylland. B: North-west of Århus. and to acknowledge their wide distribution in the subsurface (Sandersen \& Jørgensen 2003; Jørgensen et al. 2005; Jørgensen \& Sandersen 2006). Analysis of these data has revealed dense networks of tunnel valleys and has significantly improved our understanding of their distribution, geometry and sedimentary infill. In the following, we review this work and identify new perspectives for the interpretation of the Quaternary succession in Denmark.

The work was initiated in 1998 by the former Danish counties (amter), and is currently continued by the Geological Survey of Denmark and Greenland and the 'miljøcentre' (environment centres). As part of this project, the buried valleys are continuously being mapped as new data are collected.

\section{Data}

The spacing between and the quality of deep boreholes in Denmark are generally insufficient to precisely delineate buried valleys (Thomsen et al. 2004). Borehole data are, however, important as they can often be used to verify the presence of valleys indicated from geophysical data, and provide valuable information about the sedimentary infill of the valleys.

Since the coverage of boreholes is generally too sparse for proper valley delineation, other types of data distributed in denser grids are needed. Densely spaced data can be collected using the Transient Electro-Magnetic (TEM) geophysical method (Sørensen \& Auken 2004) that gives deep penetra-
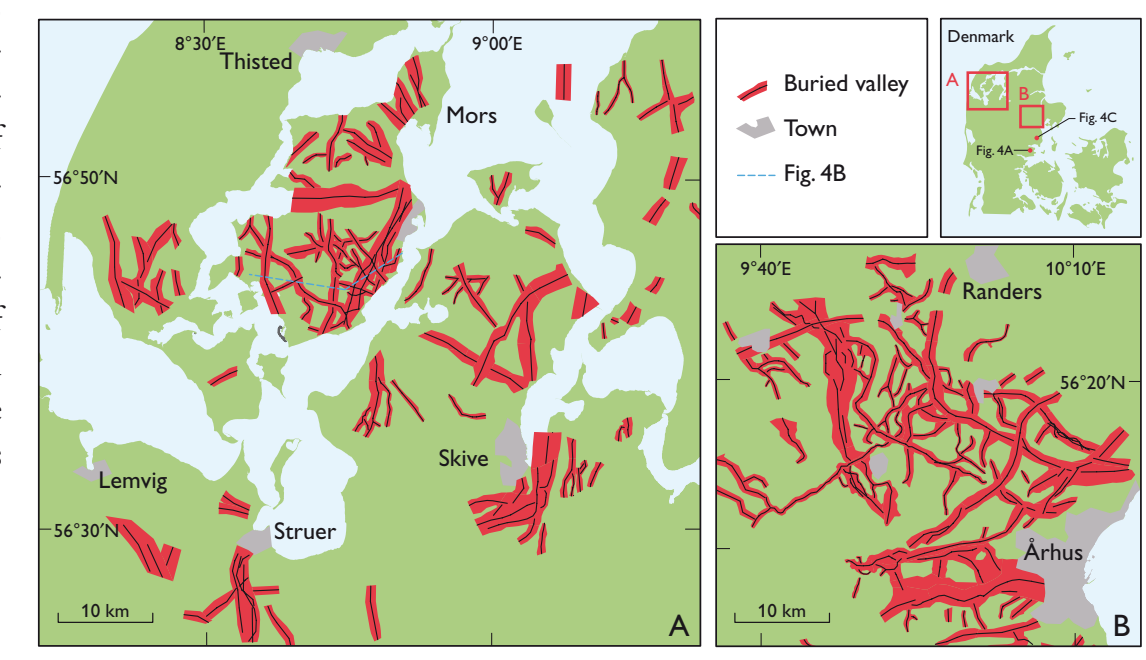
tion and an acceptable resolution. During the last ten years, this method has been extensively used in Denmark, allowing many buried valleys to be mapped.

High-resolution seismic data provide detailed 2D structural information of the valley architecture and allow detailed structural elements to be resolved, even in areas with poor lithological contrasts. However, data acquisition is costly and usually limited to widely spaced lines. The most effective method to map and investigate buried valleys is using a combination of the TEM method, seismic data and borehole data (Jørgensen et al. 2003).

In the present project, all available and relevant lithological and geophysical data from the Danish onshore area are being evaluated and examined in order to map and describe buried valleys (Sandersen \& Jørgensen 2006). A set of criteria is used to obtain a high degree of certainty and objectivity in the valley delineation. The most important criterion is that the lateral extent and the orientation of the valleys must be unambiguously expressed in the available data. No interpolations between surveyed areas are made.

\section{Valley characteristics}

More than $2500 \mathrm{~km}$ of buried valleys have currently been mapped in Denmark using this procedure. The highest valley density is found in areas where TEM data have been collected in dense grids and where the conditions for this specific method are ideal. Such areas are found, for example, northwest of Århus and in the north-western part of Jylland (Fig. 1). Although many buried valleys have been mapped in these areas, even more are expected to exist because (1) not all valleys can be mapped with the methods in use, and (2) the study areas are not yet entirely covered by such data.

Only a minor part of the country has been surveyed by the TEM method and all valleys are not represented in the collected data, so the maps can at best be considered to show the minimum occurrence of buried valleys. The general distribution and density of buried valleys therefore cannot be directly seen from the maps. Thus, while a limited number of valleys have been mapped in western Jylland, seismic data and borehole data indicate that many more buried valleys are present in this part of Denmark than shown in Fig. 2. Delineation of buried valleys in western Jylland is difficult due to low data coverage.

The buried valleys can be divided into different generations that were formed during successive glaciations (Jørgensen $e t$ al. 2005; Jørgensen \& Sandersen 2006). The valleys often cross-cut each other and sometimes they have different preferred orientations. A complicated pattern with three to five generations of valleys can often be distinguished in areas with high data resolution (Fig. 3). If the ice flows were parallel or

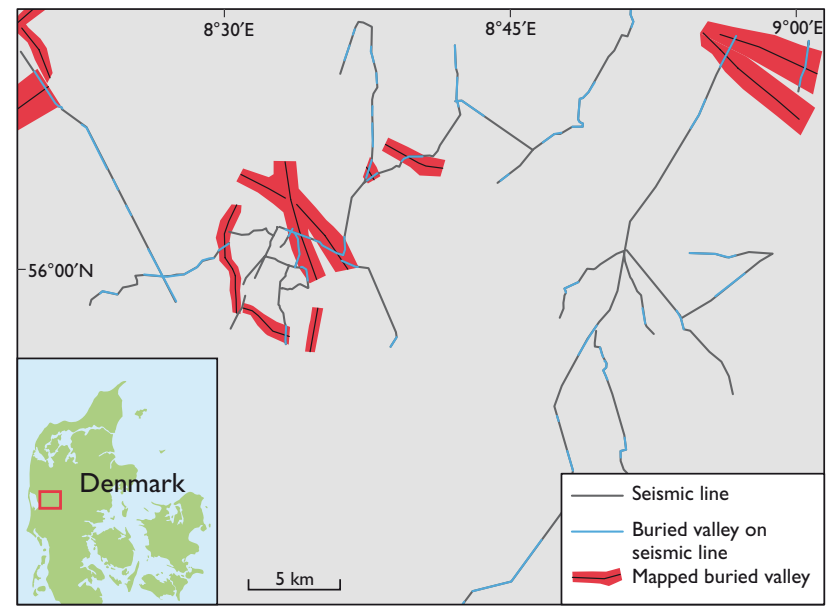

Fig. 2. Map of an area in western Jyllland, showing the location of highresolution reflection seismic lines. The buried valleys cannot be accurately mapped from data obtained by this method alone, due to the wide line spacing. The valleys shown have mainly been mapped from data obtained by area-covering methods such as the TEM method. Modified from Sandersen \& Jørgensen (2006).

nearly-parallel to pre-existing valleys, these valleys would be liable to repeated erosion and re-filling producing a complicated cut-and-fill setting within them. Multiple generations of valley erosion are therefore also often found within the buried valleys themselves. The valley architecture is normally complex due to this cut-and-fill history, but also due to glaciotectonic disturbances. This complexity can be observed in both seismic and TEM data (Fig. 4). The complex fill is also often indicated by borehole data that show strong lithological variations over short distances.

The valley fill is deposited in subglacial environments, in glacial lakes and rivers, in marine and terrestrial environments. Statistical analyses of borehole data in all the mapped valleys show that by far the most common infill sediment types are tills and meltwater deposits (Sandersen \& Jørgensen 2006). In this group, $52 \%$ are coarse meltwater deposits (sand and gravel), 30\% are clay-rich till and 18\% are finegrained meltwater deposits (silt and clay).

The mapped buried valleys vary in depth with the deepest features exceeding $350 \mathrm{~m}$ from valley floor to shoulder (Jørgensen \& Sandersen 2006). The width is generally between 0.5 and $1.5 \mathrm{~km}$, but widths of up to $4 \mathrm{~km}$ occur. The lengths of the valleys are difficult to evaluate, because many of the areas surveyed so far are small. However, some valleys in larger survey areas exceed $25-30 \mathrm{~km}$ in length. Some striking features of the valleys are that they often terminate abruptly and that they are highly irregular with depressions and thresholds along their floors.

It is difficult to determine the ages of the buried valleys. The infill sediments can be dated in some cases and provide a minimum age for the time of valley erosion. However, based on the 

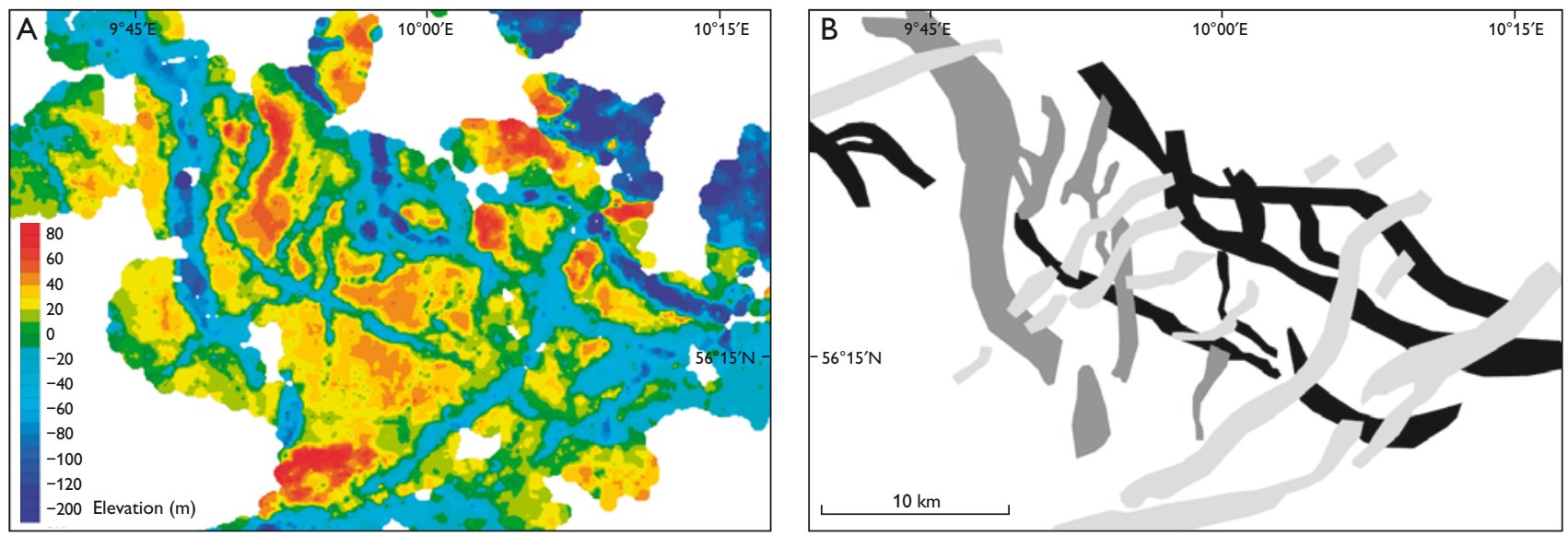

Fig. 3. A: Map of an area north-west of Århus showing the interpolated surface of a low-resistive bottom layer in TEM soundings. Large parts of the valleys have been eroded into this surface. B: Cross-cutting valley generations found in the same area. Black represents the oldest generation; light grey the youngest generation. Modified from Jørgensen \& Sandersen (2006).

time gap between the age of the eroded sediments and the age of the infill sediments, buried valleys can be shown to have formed both during the Weichselian, the Saalian and the Elsterian glacial stages (Jørgensen \& Sandersen 2006). Some of the valleys were probably formed during older glacial stages.

\section{Valley formation}

The mapped buried valleys are comparable to open tunnel valleys found in the present-day Danish landscape with respect to morphology and dimensions (Jørgensen \& Sandersen 2006). Most likely, they therefore formed as tunnel valleys and were subsequently buried by younger sediments. Subglacial meltwater erosion is believed to have been responsible for most of the erosion, whereas direct glacial erosion may have contributed to the formation of the widest valleys. The presence of multiple generations of valleys shows that the area was repeatedly transgressed by glaciers during the Pleistocene (Jørgensen \& Sandersen 2006). Tunnel valleys have a pronounced tendency to be re-used dur-

Fig. 4. Three profiles showing the complex geology related to buried valleys. A: A seismic profile across a buried valley with a cut-and-fill setting. Interpretation shown by a red line. B: TEM profile across a series of valleys. C: A TEM profile across a valley with a cut-and-fill setting. Interpretations on the TEM profiles are shown with black lines. See Fig. 1 for location of the profiles. Modified from Jørgensen et al. (2005) and Jørgensen \& Sandersen (2006). ing repeated cycles of glacial erosion, which produces their cut-and-fill structure. The degree of re-use is presumably determined by differences in the morphology, erodibility and hydraulic conductivity of the substratum. However, the occurrence of pro- and subglacial permafrost may also have played an important role (Jørgensen \& Sandersen 2006).

\section{Consequences and perspectives}

Buried valleys are widespread in the Danish subsurface, occurring as complex, cross-cutting structures established during repeated erosion and infill. These characteristics require close attention when stratigraphic correlations are made, because discontinuous and complex geological settings are to be expected.
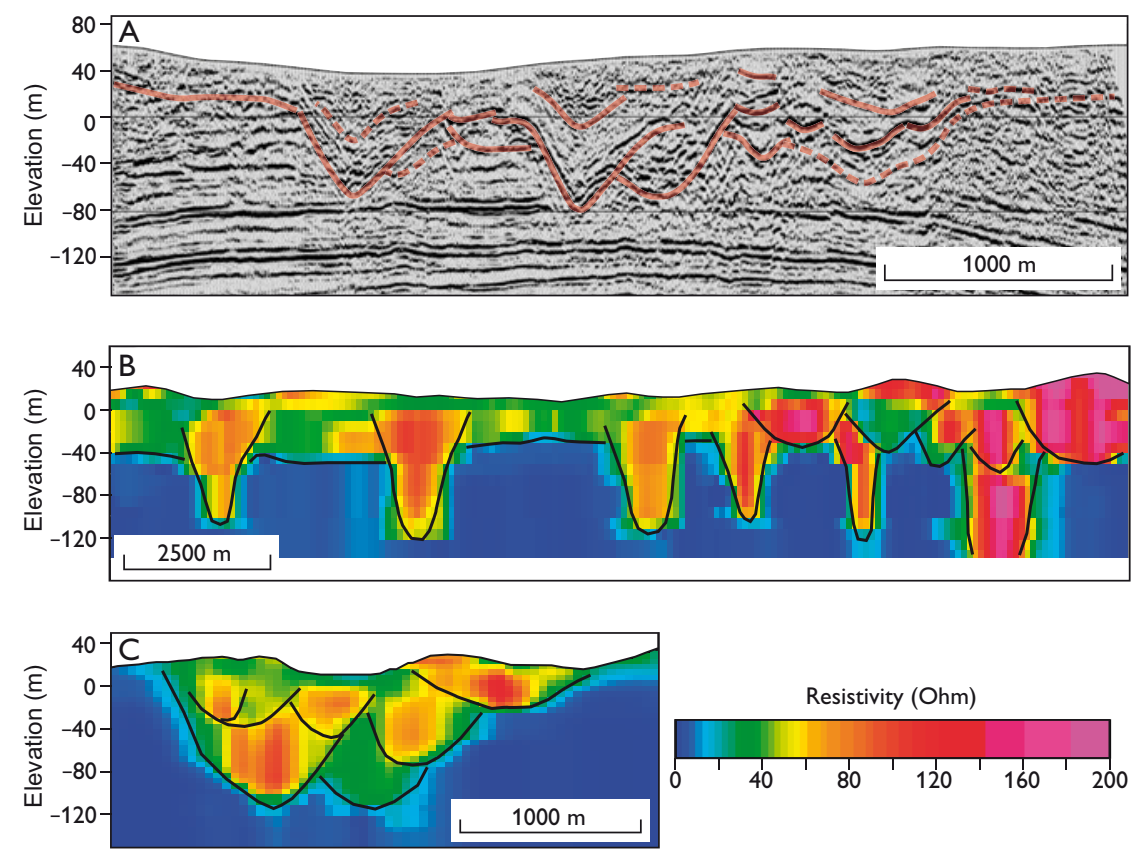
Correlation requires that the correlated sites are situated sufficiently close to each other so that they may not be significantly influenced by an unrecognised valley. The farther the valleys are apart, the more difficult correlation of their infill becomes. If one of the sites is situated inside an unrecognised or a poorly defined valley, stratigraphic correlations are likely to be erroneous, difficult or impossible to carry out. The discontinuous and complex geological setting of the valleys arises from the presence of unconformities produced by the valley erosion and from the limited lateral extent of the valleys and high variation of the sedimentary valley infill. Unconformities complicate correlations of the incised layers, and the limited lateral valley extent and high variation of the infill complicate the correlation of the infill sediments. Marked facies variations may make correlation of the infill sediments very difficult - even if the infill sediments were deposited simultaneously. The complications become even higher for valleys with cut-and-fill structures and when valleys cross-cut. Erosion of the valleys implies that much of the sedimentary record has been removed, but as erosion and sedimentation often occurred during successive events, sedimentary remnants are occasionally left behind between the unconformities. Therefore, the establishment of a coherent stratigraphy requires a dense data network and a large number of boreholes as well as a thorough knowledge of the outline and structure of the buried valleys and the relative age relationships between different valley generations in a given area. The challenges for stratigraphic correlations that arise from the presence of buried valleys as outlined above, also affect the construction of geological and hydrogeological models. Since the valleys often cross-cut older layers and contain aquifers as well as aquitards, they have the ability to significantly influence the flow regime of groundwater (e.g. Shaver \& Pusc 1992). Furthermore, chances are high that buried valleys occur in almost all parts of Denmark. In order to construct such models it is crucial to know where the valleys occur and understand how they were formed.

While the occurrence of buried valleys imposes a series of new challenges, it may also provide new possibilities for the reconstruction of the Pleistocene record. Gradually increasing knowledge and overview of the erosional and depositional history of the valleys may lead to improved general understanding of the development of the Pleistocene. It is likely that the deeper parts of some deep valleys may have withstood events of extensive glacial erosion during the Pleistocene. Thus some valleys may contain remnants of glacial or interglacial sediments, and in that case, buried valleys may contain sedimentary records from the Early and early Middle Pleistocene. Such records are currently very rarely reported from the onshore parts of Denmark.

\section{Acknowledgement}

The project is supported by the Environmental Centres in Denmark.

\section{References}

Binzer, K. \& Stockmarr, J. 1994: Geological map of Denmark, 1:500 000 Pre-Quaternary surface topography of Denmark. Danmarks Geologiske Undersøgelse Kortserie 44, 10 pp., 2 maps.

Huuse, M. \& Lykke-Andersen, H. 2000: Over-deepened Quaternary valleys in the eastern Danish North Sea: morphology and origin. Quaternary Science Reviews 19, 1233-1253.

Jørgensen, F. \& Sandersen, P.B.E. 2006: Buried and open tunnel valleys in Denmark - erosion beneath multiple ice sheets. Quaternary Science Reviews 25, 1339-1363.

Jørgensen, F., Lykke-Andersen, H., Sandersen, P.B.E., Auken, E. \& Normark, E. 2003: Geophysical investigations of buried Quaternary valleys in Denmark: an integrated application of transient electromagnetic soundings, reflection seismic surveys and exploratory drillings. Journal of Applied Geophysics 53, 215-228.

Jørgensen, F., Sandersen, P.B.E., Auken, E., Lykke-Andersen, H. \& Sørensen, K. 2005: Contributions to the geological mapping of Mors, Denmark - a study based on a large-scale TEM survey. Bulletin of the Geological Society of Denmark 52, 53-75.

Lykke-Andersen, H. 1973: En begravet dal i Præ-kvartæret ved Århus Dansk Geologisk Forening Årsskrift for 1972, 111-118.

Madsen, V. 1921: Terrainformerne på Skovbjerg Bakkeø. Danmarks Geologiske Undersøgelse IV. Række 1(12), 24 pp.

O'Cofaigh, C. 1996: Tunnel valley genesis. Progress in Physical Geography 20, 1-19.

Sandersen, P.B.E. \& Jørgensen, F. 2003: Buried Quaternary valleys in western Denmark - occurrence and inferred implications for groundwater resources and vulnerability. Journal of Applied Geophysics 53, 229-248

Sandersen, P.B.E. \& Jørgensen, F. 2006: Kortlægning af begravede dale i Jylland og på Fyn. Opdatering 2005-2006, 201 pp. De jysk-fynske amters grundvandssamarbejde. Vejle: Vejle Amt \& WaterTech A/S.

Shaver, R.B. \& Pusc, S.W. 1992: Hydraulic barriers in Pleistocene buriedvalley aquifers. Ground Water 30, 21-28.

Smed, P. 1998: Die Entstehung der dänischen und norddeutschen Rinnentäler (Tunneltäler) - Glaziologische Gesichtspunkte. Eiszeitalter und Gegenwart 48, 1-18.

Sørensen, K.I. \& Auken, E. 2004: SkyTEM - a new high-resolution helicopter transient electromagnetic system. Exploration Geophysics 35 , 191-199.

Sorgenfrei, T. \& Berthelsen, O. 1954: Geologi og vandboring. Danmarks Geologiske Undersøgelse III. Række 31, 106 pp.

Thomsen, R., Søndergaard, V.H. \& Sørensen, K.I. 2004: Hydrogeological mapping as a basis for establishing site-specific groundwater protection zones in Denmark. Hydrogeology Journal 12, 550-562.

Ussing, N.V. 1907: Om Floddale og Randmoræener i Jylland. Oversigt over Det Kongelige Danske Videnskabernes Selskabs Forhandlinger 4, $161-213$.

\footnotetext{
Authors' addresses

F.J., Geological Survey of Denmark and Greenland, Øster Voldgade 10, DK-1350 Copenhagen K, Denmark. E-mail: flj@geus.dk

P.B.E.S., Grontmij | Carl Bro A/S, Dusager 12, DK-8200 Århus N, Denmark..
} 